\title{
OBLIGACJE PODPORZĄDKOWANE, WIECZYSTE I PRZYCHODOWE W POLSCE - PRÓBA OCENY EKONOMICZNYCH SKUTKÓW NOWELIZACJI USTAWY O OBLIGACJACH
}

\section{WPROWADZENIE}

Obligacje stanowią immanentny element każdego rynku finansowego i sa jednym z najważniejszych instrumentów finansowania zwrotnego, wykorzystywanym zarówno przez podmioty publiczne (rząd, jednostki samorządu terytorialnego), jak i przedsiębiorstwa. Jednym z istotniejszych dla rynku finansowego wydarzeń prawnych 2015 r. było uchwalenie i wprowadzenie w życie nowelizacji ustawy o obligacjach ${ }^{1}$, która 1 lipca 2015 r. zastapiła dotychczasową ustawę, obowiąująca przez ostatnie 20 lat. Wśród motywów dokonania zmiany ustawy wymienia się m.in. konieczność uwzględnienia w prawodawstwie krajowym zmian, jakie dokonały się w ostatnich latach w dziedzinie prawa, organizacji i technologii.

W niniejszym artykule przedstawiono wybrane, najważniejsze zmiany dokonane w ustawie o obligacjach, w szczególności w zakresie nowych rodzajów obligacji (podporządkowanych i wieczystych) oraz zmian przepisów dotyczących obligacji przychodowych, a także podjęto rozważania na temat ich możliwych konsekwencji dla rynku analizowanych walorów. Rzeczywiste skutki nowych rozwiąań prawnych będzie można ocenić z perspektywy kilku lat, dlatego też niniejsze opracowanie należy traktować jako opinię autora, podpartą ocenami analityków rynku obligacji oraz doświadczeniami rynków rozwiniętych. Ponadto należy zaznaczyć, że analizowana w niniejszym artykule ustawa o obligacjach i jej nowelizacja nie dotyczą obligacji emitowanych przez Skarb Państwa i Narodowy Bank Polski², a podjęte rozważania odnoszą się do obligacji określnych mianem „nieskarbowych”.

1 Ustawa o obligacjach z 15 stycznia 2015 r. o obligacjach, Dz. U. 2015, poz. 238 (dalej jako: u.o.).

2 Obligacje skarbowe i obligacje NBP regulowane są odrębnymi przepisami, w tym w szczególności ustawy z 27 sierpnia 2009 r. o finansach publicznych, Dz. U. Nr 157, poz. 1240, rozdział 5 i ustawy z 19 sierpnia 1997 r. o Narodowym Banku Polskim, Dz. U. Nr 140, poz. 938, art. 48. 


\section{USTAWA O OBLIGACJACH Z 1995 R. - DOTYCHCZASOWE ROZWIAZANIA PRAWNE I KONIECZNOŚĆ DOKONANIA ICH ZMIANY}

Na wstępie podjętych rozważań należy zdefiniować pojęcie obligacji i opisać krótko historię funkcjonowania tego instrumentu w Polsce, aby na tym tle pokazać znaczenie ustawy o obligacjach z $1995 \mathrm{r}$. i potrzebę jej nowelizacji.

Obligacja wyraża zobowiązanie (stosunek prawny) pomiędzy jej emitentem a właścicielem obligacji. Zasadniczo kupujący obligację finansuje w sposób zwrotny emitenta, a ten zobowiąuje się do zwrotu uzyskanej kwoty oraz ustalonych odsetek w określonych terminach i w ustalony sposób ${ }^{3}$. Przedstawiona definicja określa obligację jako klasyczny instrument dłużny i w takiej postaci występuje ona najczęściej. Jednakże konstrukcja zobowiązania wynikającego z obligacji może przyjmować różne warianty, różniące się między sobą przede wszystkim zakresem praw i obowiązków stron opisywanego stosunku prawnego.

Obligacje są instrumentem finansowym stosowanym w Polsce już od wielu lat, a pierwsze regulacje prawne dotyczące ich emisji sięgają dwudziestolecia międzywojennego ${ }^{4}$. Na samym początku okresu transformacji - początek lat dziewięćdziesiątych XX w. - były to wyłącznie obligacje skarbowe, które służyły finansowaniu deficytów budżetowych. Wraz ze stabilizacją sytuacji ekonomicznej kraju obserwowalne było wydłużanie okresu wykupu nowych emisji tych walorów ${ }^{5}$. Oprócz Skarbu Państwa emisja opisywanych instrumentów dłużnych zainteresowane były również inne podmioty, w tym prywatne. Emisję obligacji komunalnych (emitowanych przez jednostki samorządu terytorialnego) oraz obligacji przedsiębiorstw umożliwiła ustawa o obligacjach z 29 czerwca 1995 r. ${ }^{6}$ Oczekiwano, że przepisy tej ustawy pozwola rozwinać rynek nieskarbowych papierów wartościowych, a obligacja stanie się realną alternatywą dla kredytów bankowych. Już na początku XXI w. wskazywano na to, że zwiększa się znaczenie tego instrumentu, co możliwe jest dzięki przewidywalności parametrów makroekonomicznych (w szczególności stabilnej inflacji) oraz coraz to większej potrzebie finansowania działalności przedsiębiorstw za pomoca kapitałów obcych? .

Opisywana ustawa została uchwalona w 1995 r., a ważniejsza jej nowelizacja, liberalizująca dotychczasowe przepisy - w 2000 r. Skutki wprowadzo-

${ }^{3}$ E. Gruszczyńska-Brożbar, Obligacje instrumentami rynku długoterminowych kapitałów pieniężnych, w: W. Przybylska-Kapuścińska (red.), Rynek papierów wartościowych w Polsce. Wybrane problemy, Wyd. AE w Poznaniu, Poznań 2002, s. 97.

${ }^{4} \mathrm{~W}$ niniejszym artykule pominięto prezentację historii obligacji w Polsce. Szerzej na ten temat w: M. Pawłowski, Rynek obligacji korporacyjnych $w$ Polsce. Uwarunkowania i perspektywy rozwoju, CeDeWu, Warszawa 2015, s. 59-66.

${ }^{5}$ W. Bień, Rynek papierów wartościowych, Difin, Warszawa 1998, s. 63.

${ }^{6}$ Ustawa z 29 czerwca 1995 r. o obligacjach, Dz. U. 1995, Nr 83, poz. 420 ze zm.

7 J. Socha, Rynek papierów wartościowych w Polsce, Olympus, Warszawa 2003, s. 120. 
nych zmian były znaczące dla rynku obligacji przedsiębiorstw, który w pięć lat po nowelizacji powiększył się trzykrotnie pod względem wartości ${ }^{8}$. Podobnie obserwowalne było zwiększenie dynamiki wzrostu wartości obligacji komunalnych po 2000 r., co miało jednak również związek z reformą samorządową i zwiększeniem się liczby jednostek samorządu terytorialnego w Polsce ${ }^{9}$. Zatem okres kilku pierwszych lat nowego stulecia należy ocenić pozytywnie z punktu widzenia rozwoju rynku obligacji nieskarbowych. Jednakże kolejne lata na rynku obligacji nie były już takie optymistyczne, na co nałożył się także negatywny wpływ kryzysu finansowego, skutkiem czego w 2009 r. odnotowano ujemną dynamiką wartości badanych obligacji - zarówno korporacyjnych, jak i komunalnych. Dopiero od 2010 r. odnotować można ponownie wzrosty wartości obligacji, a ogólna kapitalizacja rynku na wrzesień 2015 r. wynosiła 126,9 mld zł (bez obligacji infrastrukturalnych BGK) ${ }^{10}$. Jednakże ostatnie dziesięciolecie to okres wielu istotnych przeobrażeń na rynku nieskarbowych papierów dłużnych, wśród których za najważniejsze należy uznać zmiany prawne, organizacyjne i technologiczne, które sprawiły, że ustawa o obligacjach z 1995 r. okazała się w wielu rozwiąaniach niewystarczająca ${ }^{11}$.

Do najważniejszych zmian prawnych należy zaliczyć m.in. uchwalenie w 2005 r. ustaw zmieniajacych funkcjonowanie publicznego obrotu papierami wartościowymi ${ }^{12}$, jak również ustawy o nadzorze nad rynkiem finansowym z 2006 r. ${ }^{13}$ i o funduszach inwestycyjnych z 2004 r. ${ }^{14}$, a także wdrażanie norm ostrożnościowych w sektorze bankowym i ubezpieczeniowym (związanych przede wszystkim z adekwatnością kapitałową tych instytucji i zarządzaniem ryzykiem - Basel II i III ${ }^{15}$ oraz Solvency $\mathrm{II}^{16}$ ). Ewolucja krajowego systemu

8 S. Antkiewicz, Rynek dtużnych papierów wartościowych w Polsce-instrumenty, innowacje, perspektywy, Wyd. UG, Gdańsk 2006, s. 89.

${ }^{9}$ P. Śliwiński, K. Grybionko, Rynek obligacji komunalnych w Polsce, w: P. Śliwiński, M. Stępniewski (red.), Obligacje komunalne - zagadnienia prawne, finansowe, praktyczne, Twigger, Warszawa 2009, s. 220-225.

${ }_{10}$ Rating \& rynek, „Fitch Polska” 2015, nr 10(338), s. 80.

${ }^{11}$ Przytaczane uwagi stanowią fragment Opinii merytorycznej na temat rzadowego projektu ustawy o obligacjach (druk sejmowy nr 2735), którą autor sporządził w październiku 2014 r. na wniosek Kancelarii Sejmu RP.

${ }^{12}$ W szczególności: ustawa z 29 lipca 2005 r. o obrocie instrumentami finansowymi, Dz. U. $\mathrm{Nr}$ 183, poz. 1538; ustawa z 29 lipca 2005 r. o ofercie publicznej i warunkach wprowadzania instrumentów finansowych do zorganizowanego systemu obrotu oraz o spółkach publicznych, Dz. U. Nr 184, poz. 1539.

${ }^{13}$ Ustawa z 21 lipca 2006 r. o nadzorze nad rynkiem finansowym, Dz. U. Nr 157, poz. 1119.

14 Ustawa z 27 maja 2004 r. o funduszach inwestycyjnych, Dz. U. Nr 146, poz. 1546.

${ }_{15}$ Rozwiązania określane mianem Basel I, II i III oznaczają kolejne zbiory metod wypracowanych przez Bazylejski Komitet Nadzoru Bankowego w ostatnich kilkudziesięciu latach w celu wzmocnienia nadzoru nad bankami. Wdrażanie opracowanych metod ma na celu ochronę bezpieczeństwa sektora bankowego głównie przez odpowiednie zarządzanie ryzykiem i spełnianie przez banki wymagań kapitałowych. Szerzej na ten temat w: A Brief History of the Basel Committee, Basel Committee on Banking Supervision, October 2015.

${ }_{16}$ Projekty Solvency I i II stanowią zbiór reform dotyczących wypłacalności zakładów ubezpieczeń, które analogicznie jak w przypadku banków, sprowadzają się, generalnie rzecz biorąc, do zarządzania ryzykiem i nadzoru nad działalnością ubezpieczeniowa. Szerzej na ten temat 
prawnego spowodowała, że przepisy ustawy o obligacjach z $1995 \mathrm{r}$. w konfrontacji z innymi aktami prawnymi okazywały się niejasne i wzbudzały watpliwości, co skutkowało niepewnością wśród uczestników rynku, przekładającą się na spowolnianie rozwoju rynku tych walorów.

W zakresie organizacji obrotu obligacjami nastapiły także znaczące zmiany, wśród których za najważniejszą należy uznać powstanie w 2009 r. rynku Catalyst. Rynek ten prowadzony jest na platformach transakcyjnych Giełdy Papierów Wartościowych w Warszawie i BondSpot, z których każda funkcjonuje $\mathrm{w}$ formie rynku regulowanego i alternatywnego systemu obrotu. W grudniu 2015 r. na rynku notowanych było ponad 500 serii obligacji na łączną kwotę powyżej $570 \mathrm{mld}$ zł i ok. 9 mld euro. Same obligacje nieskarbowe opiewają zaledwie na kwotę ok. 61 mld zł, tj. 10-11\% ogółu obligacji złotowych (pod względem ich wartości). Grono emitentów nieskarbowych w grudniu 2015 r. liczyło 189 podmiotów, wśród których dominowały przedsiębiorstwa (146), w mniejszości zaś były spółdzielnie (22) i jednostki samorządu terytorialnego (19) ${ }^{17}$. Dane te pokazuja, w jak małym stopniu rynek nieskarbowych papierów dłużnych jest wykorzystywany, co wynika m.in. z konieczności zmiany podstaw prawnych dotyczących obligacji.

Ponadto ostatnie kilkanaście lat to również okres wielu zmian w zakresie technologii informacyjnych. Nowe rozwiązania w zakresie technicznych aspektów emisji i obrotu papierami wartościowymi mają charakter rozwiązań usprawniających funkcjonowanie rynku papierów wartościowych, a także zwiększających bezpieczeństwo jego użytkowników. Współczesny świat technologii informacyjnych, którego osiągnięcia są przyjmowane i stosowane przez uczestników rynku finansowego w codziennym życiu, wymusza również dostosowanie współczesnego prawa. Stąd wynikała chociażby konieczność dokonania zmian w zakresie wymogów formalnych dotyczacych prezentowania informacji, w tym np. sprawozdań finansowych za pośrednictwem Internetu, czy też wymogów formalnych związanych z korespondencja pomiędzy stronami stosunku prawnego, która powinna dokonywać się także drogą elektroniczna.

\section{USTAWA O OBLIGACJACH Z 2015 R. - ZASADNICZE ELEMENTY NOWELIZACJI}

Zdaniem wielu analityków rynek nieskarbowych papierów wartościowych nie rozwijał się w odpowiednim tempie, co wynikało z nieadekwatności ustawy o obligacjach z $1995 \mathrm{r}$. do wymagań współczesności. Opisane w poprzednim punkcie zmiany na rynku tych walorów i w jego otoczeniu wskazywały na

\footnotetext{
w: Wypłacalność podmiotów sektora ubezpieczeniowego (Solvency I i II), Komisja Nadzoru Finansowego, www.knf.gov.pl.

${ }^{17}$ Zob. www.gpwcatalyst.pl [dostęp: 15.12.2015]
} 
potrzebę rozwiązania narosłych problemów na drodze inicjatywy ustawodawczej. Z takiej możliwości skorzystał rząd RP, kierując 8 września 2014 r. do Sejmu projekt nowej ustawy o obligacjach ${ }^{18}$.

Projektodawcy wskazywali na powolny rozwój rynku nieskarbowych papierów wartościowych, ilustrując ten fakt ogromną dysproporcją pomiędzy liczba i wartością wyemitowanych obligacji w porównaniu z liczbą i wartością kredytów jako alternatywnej formy finansowania. Przygotowany projekt ustawy miał na celu „wsparcie w długim okresie rozwoju rynku długoterminowych nieskarbowych papierów dłużnych”. Wykazane przez autorów projektu mankamenty obowiązujących wcześniej rozwiązań prawnych mogły zostać rozwiązane przez uchwalenie ustawy na nowo ${ }^{19}$.

Projekt nowej ustawy wpłyną do Sejmu RP 9 września 2014 r., był procedowany w Komisji Finansów Publicznych, konsultowany m.in. z organizacjami samorządowymi, a po trzecim czytaniu skierowany do Senatu. Ostatecznie po poprawkach Sejm 15 stycznia 2015 r. przyją ustawę, która została podpisana przez Prezydenta RP, a jej przepisy weszły $\mathrm{w}$ życie 1 lipca 2015 r. ${ }^{20}$

Zmiany w ustawie - według autorów noweli - miały na celu prawne wsparcie rozwoju rynku obligacji nieskarbowych przez:

- umożliwienie dokonywania skutecznych zmian w stosunku zobowiązaniowym wynikającym z obligacji (wprowadzenie podstaw funkcjonowania zgromadzenia obligatariuszy),

- rozszerzenie zakresu instrumentów dostępnych dla emitenta (wprowadzenie obligacji podporządkowanych oraz obligacji wieczystych),

- rozstrzygnięcie wątpliwości towarzyszących obowiązującym regulacjom ${ }^{21}$.

Należy zaznaczyć, że wprowadzone zmiany mają charakter ewolucyjny. Nowa ustawa nie zrywa z dziedzictwem i dorobkiem poprzedniej, ale jest jej rozwinięciem, uporządkowaniem i uaktualnieniem. Przeważająca część jej przepisów oparta jest na regulacjach dotychczasowej ustawy, stąd zasadniczo - z prawnego punktu widzenia - aktualne pozostaja stanowiska przedstawicieli doktryny i judykatury przy dokonywaniu wykładni jej przepisów $^{22}$.

W nowej ustawie wprowadzono wiele zmian, których z uwagi na objętość nie sposób opisać w niniejszym opracowaniu. Wybrano najważniejsze z nich, które, jak się wydaje, będą miały największe znaczenie dla uczestników rynku obligacji nieskarbowych w Polsce - wymieniono je w tabeli 1.

\footnotetext{
18 Druk nr 2735.

19 Uzasadnienie projektu ustawy o obligacjach, druk nr 2735.

${ }^{20}$ Przebieg procesu legislacyjnego, druk nr 2735, Sejm RP, www.sejm.gov.pl.

21 Uzasadnienie..., op. cit.

22 R. Woźniak, Ustawa o obligacjach. Komentarz, C. H. Beck, Warszawa 2015, s. IX-X.
} 


\section{Tabela 1}

Najważniejsze zmiany prawne wynikające z nowelizacji ustawy o obligacjach

\begin{tabular}{|c|c|}
\hline Rodzaj zmiany & Krótka charakterystyka \\
\hline $\begin{array}{l}\text { Nowe rodzaje obligacji } \\
\text { (art. } 22 \text { i } 23 \text { ) }\end{array}$ & $\begin{array}{l}\text { - wprowadzenie dwóch nowych rodzajów obligacji: } \\
\text { - obligacje podporządkowane - w przypadku ogłoszenia } \\
\text { upadłości emitenta roszczenia obligatariuszy zaspokajane } \\
\text { są po innych wierzycielach } \\
\text { - obligacje wieczyste - niepodlegające wykupowi (co do za- } \\
\text { sady), zobowiązujące emitenta do płatności odsetek przez } \\
\text { czas nieokreślony }\end{array}$ \\
\hline $\begin{array}{l}\text { Zgromadzenie obligata- } \\
\text { riuszy (rozdz. } 5 \text { ) }\end{array}$ & $\begin{array}{l}\text { - uregulowanie funkcjonowania zgromadzenia obligatariuszy } \\
\text { i jego kompetencji na wzór walnego zgromadzenia akcjonariu- } \\
\text { szy zapisanych w Kodeksie spółek handlowych } \\
\text { przyznanie zgromadzeniu uprawnienia do zmiany warunków } \\
\text { emisji obligacji }\end{array}$ \\
\hline $\begin{array}{l}\text { Obowiazki informacyj- } \\
\text { ne emitenta (art. 6) }\end{array}$ & $\begin{array}{l}\text { - szczegółowe zdefiniowanie warunków emisji (elementów tego } \\
\text { dokumentu) }\end{array}$ \\
\hline $\begin{array}{l}\text { Inne ważniejsze } \\
\text { zmiany }\end{array}$ & 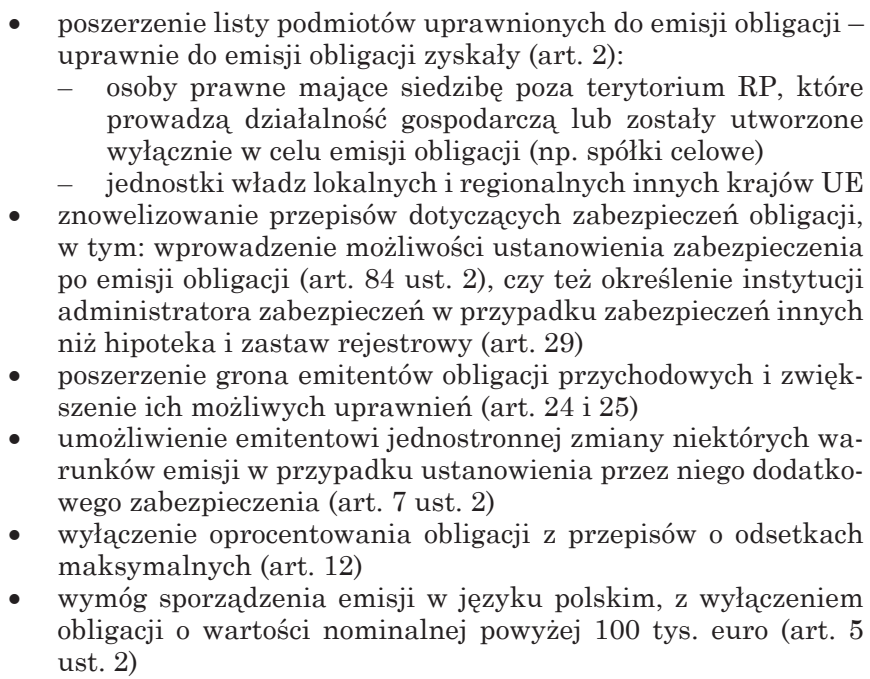 \\
\hline
\end{tabular}

Źródło: opracowanie własne na podstawie: ustawa z 15 stycznia 2015 r. o obligacjach, Dz. U. 2015, poz. 238; R. Woźniak, op. cit.; T. Gałka, Ewolucja rynku obligacji korporacyjnych w Polsce, CASE, Warszawa, 5 marca 2015 r., s. 10; Obligacje po zmianach, Alert prawny nr 10/2015, Deloitte.

W niniejszym artykule skoncentrowano się przede wszystkim na nowych rodzajach obligacji (obligacjach podporządkowanych i wieczystych), a także na istotnych zmianach wspierajacych istniejące już, a stosowane w znikomym zakresie obligacje przychodowe. Tym rozwiązaniom poświęcone zostały osobne punkty. 


\section{OBLIGACJE PODPORZĄDKOWANE I WIECZYSTE - NOWE RODZAJE OBLIGACJI W POLSCE I POTENCJALNE SKUTKI ICH EMISJI}

Jak wskazano w poprzednim punkcie, nowa ustawa wprowadza dwa nowe rodzaje obligacji, które mogą być emitowane w Polsce - obligacje wieczyste i obligacje podporządkowane. Rozwiązania te nie są nowe, gdyż od wielu lat stosowane są na świecie - nie były one jednak do tej pory uregulowane przepisami polskiego prawa.

Pierwszym z nowych rodzajów obligacji, które znalazły się w ustawie, sa obligacje podporządkow ane $\mathrm{e}^{23}$. W warunkach emisji tych obligacji emitent wskazuje, że w przypadku jego upadłości lub likwidacji roszczenia obligatariuszy podporządkowanych zostaną zaspokojone po zaspokojeniu innych wierzycieli emitenta. Należy zatem od razu zauważyć, że grono potencjalnych emitentów tych obligacji ogranicza się do podmiotów, których upadłość można ogłosić. Zatem w gronie potencjalnych emitentów tych obligacji nie mogą się znaleźć przykładowo jednostki samorządu terytorialnego ${ }^{24}$.

Fakt uregulowania w polskim prawie instytucji obligacji podporządkowanych należy ocenić pozytywnie. Wynika to z coraz częstszego wykorzystywania na świecie, ale również w Polsce instytucji długu podporządkowanego (ang. subordinated debt) do finansowania działalności różnego rodzaju przedsiębiorstw - finansowych i niefinansowych. W przypadku przedsiębiorstw finansowych sprawa dotyczy przede wszystkim banków, które w myśl wdrażanych wymogów dotyczących ich adekwatności kapitałowej mogą zaliczać dług podporządkowany do kapitałów własnych. Kapitały własne mają w znaczącej części zapewniać bezpieczeństwo ich funkcjonowania oraz całego sektora bankowego. Wdrożona w Polsce Nowa umowa kapitałowa (Basel II), o której wspomniano już wcześniej, wskazuje, że mogą być to pożyczki podporządkowane z pierwotnym okresem zapadalności wynoszącym przynajmniej 2 lata, przy czym okres ten zostanie wydłużony do 5 lat zgodnie $\mathrm{z}$ postanowieniami kolejnej „umowy kapitałowej” - Basel III. Wprowadzane do prawodawstwa krajów członkowskich postanowienia tej umowy (przyjętej dyrektywa Parlamentu i Rady 2013/36/UE ${ }^{25}$ oraz rozporządzeniem Parlamentu i Rady nr 575/2013 ${ }^{26}$ ) określają możliwość zaliczania do kapitałów własnych banku kapitału „drugiej kategorii” (tier II) pod postacią „pożyczek podporządkowanych”, do których zaliczyć można także obligacje podporządkowane. Wyko-

23 Art. 22 u.o.

${ }^{24}$ Listę podmiotów, które nie mogą ogłosić upadłość, definiuje ustawa z 28 lutego 2003 r. Prawo upadłościowe i naprawcze, Dz. U. Nr 60, poz. 535 ze zm., art. 6.

${ }^{25}$ Dyrektywa Parlamentu Europejskiego i Rady 2013/36/UE z 26 czerwca 2013 r. w sprawie warunków dopuszczenia instytucji kredytowych do działalności oraz nadzoru ostrożnościowego nad instytucjami kredytowymi i firmami inwestycyjnymi, zmieniająca dyrektywę 2002/87/WE i uchylająca dyrektywy 2006/48/WE oraz 2006/49/WE, Dz. Urz. UE L 176/338.

${ }_{26}$ Rozporządzenie Parlamentu Europejskiego i Rady nr 575/2013 z 26 czerwca 2013 r. w sprawie wymogów ostrożnościowych dla instytucji kredytowych i firm inwestycyjnych, zmieniające rozporządzenie (UE) nr 648/2012, Dz. Urz. UE L 176/1. 
rzystanie takiego instrumentu finansowania długoterminowego obserwuje się wśród banków w Polsce od przynajmniej kilku lat. Banki emitowały takie obligacje pod rządami poprzedniej ustawy, zaznaczajac w dokumencie emisyjnym, że zgromadzone dzięki emisji środki stanowić będą część funduszy uzupełniających banku ${ }^{27}$ - zgodnie z przepisami Prawa bankowego ${ }^{28}$.

Potrzebę nowych regulacji potwierdza fakt, że zostały one już wykorzystane w praktyce po nowelizacji ustawy. Przykładowo, emisji obligacji podporząkowanych - z powołaniem się na art. 22 nowej ustawy o obligacjach - dokonał w grudniu 2015 r. Getin Noble Bank S.A. ${ }^{29}$ Dyskusyjna pozostaje oczywiście skala możliwości wykorzystywania nowego rodzaju obligacji jako kapitałów własnych banku. Opisywany bank dokonał już emisji takich obligacji i struktura jego kapitałów wydawać się może niekorzystna z uwagi na nadmierny udział długu podporządkowanego w kapitałach własnych banku w stosunku do kapitału podstawowego ${ }^{30}$. Zdefiniowanie nowego rodzaju obligacji należy jednak ocenić pozytywnie, gdyż występuje realna potrzeba wykorzystywania takich instrumentów, jakkolwiek to rynek w najbliższych latach oceni, na jaka skalę banki będą mogły korzystać z tej formy finansowania.

Podobnie rzecz ma się w przypadku ubezpieczycieli, których dotyczy analogiczna do bankowej „umowa kapitałowa” (Solvency II). Z doniesień prasowych można się dowiedzieć o próbach emisji obligacji podporządkowanych przez największego polskiego ubezpieczyciela ${ }^{31}$.

Idea obligacji podporządkowanych wyklucza istnienie jakichkolwiek innych zabezpieczeń niż dobre imię emitenta, co wynika z samej definicji obligacji zawartej w art. 22 ustawy o obligacjach z 2015 r. Jednakże samo „podporządkowanie” w żaden sposób nie ogranicza ani nie umniejsza odpowiedzialności emitenta. W przypadku wystapienia upadłości lub likwidacji spółki obligatariusze dochodzą swoich roszczeń na zasadach ogólnych z zachowaniem kolejności wynikającej z warunków emisji ${ }^{32}$.

Oprócz możliwości zastosowania opisywanych obligacji przez instytucje finansowe należy wskazać, że wykorzystanie długu podporządkowanego może być sposobem finansowania projektów w zakresie partnerstwa publiczno-prywatnego (PPP). Koncepcję taką promuje UE m.in. poprzez inicjatywę Komisji Europejskiej dotycząca tzw. obligacji projektowych, realizowaną wspólnie z Europejskim Bankiem Inwestycyjnym. Inicjatywa ta ma na celu wspieranie przedsięwzięć PPP i polega (w skrócie) na tym, że strona publiczna przez

27 Takich emisji dokonał np. Bank Pocztowy w 2011 czy też mBank pod koniec 2013 r.

28 Możliwość taką daje art. 127 ust. 3 pkt 2 ustawy z 29 sierpnia 1997 r. - Prawo bankowe, Dz. U. 2015, poz. 128.

${ }_{29}$ Ostateczne warunki oferty obligacji podporzqdkowanych serii PP5-I emitowanych w ramach Publicznego Programu Emisji Obligacji Podporzadkowanych przez GETIN NOBLE BANK S.A., 20 listopada 2015 r.

${ }^{30}$ R. Janik, Uwaga na obligacje podporzadkowane. Przykład Getin Noble Banku, fairvalue. com, 15 września 2015 r.

${ }^{31}$ PZU liczy, ̇̇e wyemituje obligacje podporzadkowane bez zmian w prawie, „Puls Biznesu”, www.pb.pl, 2 października 2014 r.

32 T. Trewicz, Obligacje podporzadkowane w świetle nowelizacji ustawy o obligacjach, obligacje24.com, 20 kwietnia 2015 r. 
wniesienie do spółki celowej środków publicznych jako długu podporządkowanego (ewentualnie przez gwarantowanie tego długu, np. obligacji podporządkowanych spółki) podnosi wiarygodność kredytowa pozostałych obligacji (projektowych, „uprzywilejowanych”), co skutkuje niższym oprocentowaniem tych obligacji i obniżeniem kosztów finansowania całego przedsięwzięcia ${ }^{33}$.

Przedstawione powyżej argumenty pozwalają pozytywnie ocenić ideę przepisu ustawy wprowadzającego instytucję obligacji podporządkowanej, który rozwiewa przede wszystkim niepewność, czy taka forma długu podporządkowanego w Polsce występuje czy nie. Mankamentem nowej regulacji jest jednak to, że nie definiuje ona pojęcia „obligacja podporządkowana”, w przeciwieństwie do pozostałych rodzajów obligacji.

Drugim z nowych rodzajów obligacji, które znalazły się w przepisach ustawy, a których emisja - z uwagi na brak regulacji - nie była wcześniej w Polsce możliwa, sa obligacje wieczyste. Ten rodzaj obligacji, co do zasady, nie podlega wykupowi, a świadczenie emitenta wobec obligatariuszy przyjmuje postać odsetek wypłacanych okresowo przez czas nieoznaczony. Wykup może nastapić jedynie w przypadku ogłoszenia upadłości lub otwarcia likwidacji emitenta, zwłoki emitenta w wypłacie należnych świadczeń pieniężnych albo z innych wskazanych przez emitenta przyczyn, lecz nie wcześniej niż po 5 latach od daty emisji (z wyłączeniem likwidacji lub upadłości emitenta ${ }^{34}$. Nowa ustawa uchyla również przepis Kodeksu cywilnego, zgodnie z którym bezterminowe zobowiązania ciagłe nie są wieczyste, a każda ze stron stosunku ma kompetencje do tego, aby zakończyć zobowiąanie ${ }^{35}$.

Obligacje wieczyste (ang. perpetual bonds) wykorzystywane są powszechnie na rozwiniętych rynkach finansowych i posiadają długą historię. Przykładem pierwszych, najbardziej znanych obligacji tego typu sa konsole (ang. consols, consolidated annuities) emitowane przez rząd brytyjski już w XVIII w., dające wierzycielom rządu prawo do otrzymywania odsetek, a których wykup nie był określony „w dającej się przewidzieć przyszłości” ${ }^{36}$. Oprócz brytyjskich konsoli znane sa jeszcze starsze przypadki takich obligacji, przykładowo wyemitowane w $1646 \mathrm{r}$. holenderskie „obligacje wodne” (ang. water bonds). Walory te zostały wyemitowane przez spółkę (Hoogheemraadschap Lekdijk Bovendams) zarządzającą szeregiem tam i kanałów zlokalizowanych w dolnym biegu Renu. Pomimo upływu ponad 350 lat od emisji spółka, która przejęła uprawnienia emitenta, nadal płaci swoim obligatariuszom odsetki ${ }^{37}$.

Obecnie obligacje wieczyste sa instrumentami chętnie nabywanymi przez inwestorów z uwagi na to, że przynoszą relatywnie wyższy kupon niż obligacje zwykłe (podlegające wykupowi). Wskutek działań związanych z pomocą finan-

${ }^{33}$ Szerzej na ten temat w: K. Marchewka-Bartkowiak, M. Wiśniewski, Obligacje projektowe - nowy instrument finansowania przedsięwzięć PPP $w$ formule project finance na poziomie międzynarodowym i krajowym, „Studia BAS” 2014, nr 3(39), s. 139-157.

${ }^{34}$ Art. 23 u.o.

${ }^{35}$ Ustawa z 23 kwietnia 1964 r. - Kodeks cywilny, Dz. U. Nr 16, poz. 93, art. $365^{1}$.

${ }^{36}$ M. Yglesias, Don't repay the national debt, „Slate Magazine”, www.slate.com, 29 stycznia 2013 r.

${ }^{37}$ M. Cummings, A living artifact from the Dutch Golden Age: Yale's 367-year-old water bond still pays interest, „Yale News” 22 września 2015 r. 
sową krajom i poszczególnym instytucjom, które dotknął ostatni kryzys finansowy, na rynku światowym znajduje się obecnie gros bezpiecznych walorów dłużnych, jednakże ich rentowność jest niska. Taka sytuacja może skłaniać wielu inwestorów do rozważenia zakupu bardziej ryzykownych, jednakże zarazem wyżej oprocentowanych instrumentów, jakimi są obligacje wieczyste. Walory te są również bardzo atrakcyjne dla emitentów, ponieważ z uwagi na swój bezterminowy charakter przypominają bardziej kapitał niż dług. Emitenci mogą za ich pomoca pozyskać relatywnie tańszy kapitał niż za pomoca emisji akcji, dodatkowo nie zakłócając płynności rynku akcji ${ }^{38}$. Instrument ten zyskuje coraz bardziej na popularności - przykładowo w Stanach Zjednoczonych w 2015 r. wartość emisji nowych obligacji wieczystych emitowanych przez przedsiębiorstwa osiagnęła wartość 38 mld dolarów, najwyższy poziom od 20 lat $^{39}$.

Można spotkać opinie, że w przypadku emisji dokonywanych przez przedsiębiorstwa „obligacjom wieczystym jest bardzo blisko do akcji niemych”, czyli takich, które dają akcjonariuszowi prawo dywidendy bez prawa głosu ${ }^{40}$. Dlatego też nowe przepisy krytykowane są z uwagi na to, że emisja obligacji wieczystych nie wymaga zgody organu decydujacego o podziale zysku, na co wskazywała Komisja Nadzoru Finansowego ${ }^{41}$. Należy jednak zaznaczyć, że opisywane obligacje nie dają inwestorom prawa własności przedsiębiorstwa, które je wyemitowało. Ponadto obligacje te moga podlegać (jeśli tak przewidziano w warunkach emisji) wykupowi przez emitenta, nie wcześniej jednak niż po 5 latach od ich emisji ${ }^{42}$.

Emisja obligacji wieczystych mogą być zainteresowane m.in. - wspominane już wcześniej - banki. Powodem, dla którego tak może być, jest fakt, że wspomniana już „umowa kapitałowa” pozwala zaliczyć te walory do kapitałów własnych (tier I). Dyskusyjną pozostaje oczywiście kwestia, w jakim stopniu skomplikowane co do swojej struktury moga być kapitały banku. Podmioty regulujace rynek bankowy, w szczególności jego bezpieczeństwo, jak dotąd wychodzą naprzeciw nowym rozwiązaniom, wzbogacając wachlarz instrumentów, które banki mogą zaliczyć do kapitałów własnych na potrzeby kalkulowania wymogów ostrożnościowych. Obligacje wieczyste w tej sytuacji stanowia interesujące zarówno dla banków, jak i inwestorów rozwiązanie, jednakże nasuwa się pytanie, jak wysoko będą musiały być oprocentowane, aby przyciagnąć inwestorów i jednocześnie nie zachwiać struktury własnościowej banku z punktu widzenia akcjonariuszy.

Kwestią wątpliwą pozostaje również możliwość emitowania obligacji wieczystych przez samorządy. Eksperci sceptycznie zapatrują się na to z uwagi, po pierwsze, na relatywnie niski poziom zaufania inwestorów do jednostek

${ }^{38}$ N. Brereton-Fukui, Low interest rates could spur perpetual bonds, „The Washington Post”, www.wsj.com, 24 lipca $2011 \mathrm{r}$.

${ }^{39}$ R. Atkins, T. Hale, Companies issue record levels of perpetual debt, „Financial Times”, www.ft.com, 15 czerwca 2015 r.

${ }^{40}$ Zgodnie z art. 353 § 3 ustawy z 15 września 2000 r. - Kodeks spółek handlowych, Dz. U. Nr 94, poz. 1037.

${ }^{41}$ E. Szweda, Ustawa o obligacjach. Komentarz praktyków, „Parkiet”, www.parkiet.com, 30 lipca $2015 \mathrm{r}$.

${ }^{42}$ R. Woźniak, op. cit., s. 216. 
samorządu terytorialnego. Emisje tych walorów dokonywały w historii głównie rządy centralne lub ewentualnie banki i trudno szukać w Polsce jednostek (poza największymi metropoliami), które cechowałyby się podobnym zaufaniem inwestorów co te podmioty. Po drugie, obecnie większość emisji obligacji samorządowych stanowią emisje niepubliczne, obligacje wieczyste zaś wymagaja - ze względu na wysokość emisji i konieczność obligatoryjnej wypłaty renty wieczystej - rynku publicznego ${ }^{43}$.

Podsumowując przedstawione powyżej uwagi, można uznać wprowadzenie przepisów ustanawiających obligacje wieczyste za uzasadnione i potrzebne do rozwoju rynku obligacji w Polsce. Podobnie jak w przypadku obligacji podporządkowanych - to rynek określi, czy będzie to popularny w Polsce instrument.

\section{ZMIANY W ZAKRESIE OBLIGACJI PRZYCHODOWYCH I ICH POTENCJALNE SKUTKI}

Instytucja obligacji przychodowych (ang. revenue bonds) funkcjonowała w Polsce już pod rządami poprzedniej ustawy. Nowelizacja wprowadziła jednak wiele istotnych zmian, które opisano w niniejszym punkcie, wskazując na ich potencjalne skutki.

Zgodnie z prawem emitent może przez emisję tych obligacji uprawnić obligatariuszy do zaspokojenia roszczeń z pierwszeństwem przed innymi jego wierzycielami z całości albo części przychodów lub całości, lub z części majątku przedsięwzięć sfinansowanych w całości albo w części ze środków uzyskanych z emisji obligacji - lub z całości, lub części przychodów z innych określonych przez niego przedsięwzięć. Co ważne, emitent może ograniczyć swoją odpowiedzialność za zobowiązania wynikające z obligacji przychodowych do kwoty przychodów lub wartości majątku przedsięwzięcia, do którego prawo zostało przyznane obligatariuszom ${ }^{44}$.

Wyjątkowość obligacji przychodowych polega na możliwości odejścia od ogólnej zasady stanowiącej, że emitent odpowiada za zobowiązania z obligacji całym swoim majątkiem. To odstępstwo tworzy unikatowy charakter obligacji przychodowych jako „obligacji z ograniczoną odpowiedzialnością" ${ }^{45}$ - potencjalne negatywne skutki nieosiagnięcia planowanych z przedsięwzięcia przychodów i niewystarczającej wartości powstałego majątku przy jednoczesnym braku innych zabezpieczeń ponosić będą obligatariusze, a nie emitent obligacji ${ }^{46}$.

Od 2000 r. eksperci wskazuja na to, że obligacje przychodowe stanowia doskonałą szansę na finansowanie inwestycji, głównie przez jednostki samorządu terytorialnego. Nowym bodźcem, który mógł przyspieszyć rozwój rynku

\footnotetext{
${ }^{43}$ M. Weber, Obligacje wieczyste nie dla każdego samorzqdu, „Rzeczpospolita”, www.rz.pl, 20 czerwca $2013 \mathrm{r}$.

${ }^{44}$ Art. 24 u.o.

${ }^{45}$ M. Klupczyński, Obligacje przychodowe a indywidualny wskaźnik spłaty zobowiazań, „Prawo Budżetowe Państwa i Samorządu" 2015, nr 1, s. 79.

${ }^{46} \mathrm{M}$. Poniatowicz, Obligacje przychodowe i sekurytyzacyjne jako innowacyjne instrumenty na polskim rynku komunalnych papierów wartościowych, „Finanse Komunalne” 2005, nr 3, s. 22.
} 
tych walorów, jest obowiąujący od 2014 r. indywidualny wskaźnik zadłużenia (IWZ) samorządów ${ }^{47}$, zgodnie z którym zdolność samorządu do zadłużania się zależy od jego historycznej zdolności do generowania nadwyżek finansowych (nadwyżki operacyjnej powiększonej o dochody ze sprzedaży majątku) ${ }^{48}$. Zaletą obligacji przychodowych - w świetle powyższego przepisu - jest możliwość pominięcia zobowiązań wynikajacych z tych walorów przy kalkulowaniu IWZ.

Pomimo oczekiwań analityków rynek obligacji nie rozwijał się do tej pory zbyt dynamicznie. Pod koniec 2014 r. instrumenty te stanowiły ok. 4\% obligacji komunalnych pozostajacych w obrocie, a ich emitentami były głównie spółki komunalne. Pierwsze emisje obligacji gminnych pojawiły się dopiero w ostatnim czasie: Lublin w 2014 i Nysa w 2015 r. Co ciekawe, w przypadku obligacji Lublina odpowiedzialność miasta nie została ograniczona do określonych przychodów i majątku. Takie rozwiązanie zostało zakwestionowane przez Regionalną Izbę Obrachunkową w Lublinie, jednakże miasto zaskarżyło rozstrzygnięcie RIO do Wojewódzkiego Sądu Administracyjnego, który orzekł, że w świetle prawa jest możliwe niewyłączanie „zwykłej” odpowiedzialności emitenta obligacji przychodowych ${ }^{49}$. Dotychczasowe emisje obligacji przychodowych przedstawiono w tabeli 2 .

\section{Tabela 2}

Emisje obligacji przychodowych w Polsce

\begin{tabular}{|l|c|c|}
\hline \multicolumn{1}{|c|}{ Nazwa emitenta } & $\begin{array}{c}\text { Kwota emisji } \\
\text { (maksymalna) }\end{array}$ & Rok emisji \\
\hline Miejskie Wodociąi i Kanalizacja w Bydgoszczy Sp. z o.o. & $600 \mathrm{mln}$ zł & 2005 \\
\hline Miejskie Przedsiębiorstwo Komunikacyjne - Łódź Sp. z o.o. & $166 \mathrm{mln}$ zł & 2006 \\
\hline Zakład Komunikacji Miejskiej w Gdańsku Sp. z o.o. & $60 \mathrm{mln}$ zł & 2010 \\
\hline Zakład Komunikacji Miejskiej w Gdańsku Sp. z o.o & $220 \mathrm{mln}$ zł & 2010 \\
\hline Przedsiębiorstwo Wodociągów i Kanalizacji w Gnieźnie & $28 \mathrm{mln}$ zł & 2012 \\
\hline Tramwaj Fordon Sp. z o.o. & $145 \mathrm{mln}$ zł & 2014 \\
\hline Miasto Lublin & $40 \mathrm{mln}$ zł & 2014 \\
\hline Miasto Nysa & $21 \mathrm{mln}$ zł & 2015 \\
\hline
\end{tabular}

Źródło: opracowanie własne.

Sposobem na ożywienie rynku obligacji przychodowych miała być zmiana przepisów w ustawie o obligacjach. Wśród zmian, które mogą pozytywnie wpłynąć na atrakcyjność tych walorów, należy wymienić:

${ }^{47} \mathrm{Na}$ temat konsekwencji wprowadzenia indywidualnego wskaźnika zadłużenia szerzej w: K. Marchewka-Bartkowiak, M. Wiśniewski, Indywidualny wskaźnik zadtużenia JST - ocena krytyczna i propozycje zmian, „Analizy BAS” 2012, nr 21(88).

${ }_{48}$ Ustawa z 27 sierpnia 2009 r. o finansach publicznych, Dz. U. Nr 157, poz. 1240, art. 243.

${ }^{49}$ M. Weber, Pierwsze gminne obligacje przychodowe, „Rzeczpospolita”, www.rz.pl, 17 lipca 2015 r. 
- rozszerzenie uprawnień obligatariuszy przychodowych przez możliwość nadania im przez emitenta pierwszeństwa do zaspokojenia roszczeń z przychodów i majątku przedsięwzięć, które zostały sfinansowane także tylko w części ze środków uzyskanych z ich emisji (art. 24 ust. 1); dotychczasowe przepisy nie określały tej kwestii jednoznacznie;

- umożliwienie emisji obligacji przychodowych spółkom utworzonym wspólnie przez kilka sasiadujących ze sobą jednostek samorządu terytorialnego (art. 25 ust. 1 pkt 1 i 4). Do tej pory przepisy dotyczace obligacji przychodowych odnosiły się wyłącznie do spółek utworzonych przez pojedynczą jednostkę samorządu terytorialnego. Wprowadzona zmiana ma duże znaczenie w kontekście realizowania przez samorządy przedsięwzięć, np. z zakresu gospodarki odpadami, czy też zaopatrywania mieszkańców w wodę;

- poszerzenie grona podmiotów mogacych emitować obligacje przychodowe z uwagi na przedmiot ich działalności. Do tej pory były to podmioty, których jedynym przedmiotem działalności było zaspokajanie potrzeb społeczności lokalnych lub wykonywanie zadań z zakresu użyteczności publicznej. Słusznie postanowiono zmienić sformułowanie ,jedyny” na „główny” przedmiot działalności (art. 25 ust. 1 pkt 5), co z pewnością powiększy zbiorowość podmiotów posiadających zdolność emisyjną. Wielu przedsiębiorców jest skłonnych inwestować w infrastrukturę z zakresu zadań publicznych, pod warunkiem że będzie istniała możliwość wykorzystania jej również dla celów komercyjnych. Zmiana ta z pewnościa powiększy grono zainteresowanych przedsiębiorców potencjalnych emitentów przedmiotowych obligacji - z korzyścią dla rozwoju rynku tych instrumentów;

- wprowadzenie klasyfikacji obligacji przychodowych na te, w przypadku których emitent ogranicza swoją odpowiedzialność do kwot przychodów i majątku przedsięwzięć sfinansowanych za ich pomoca, i te, w przypadku których emitent odpowiada bez ograniczeń, tj. całym swoim majątkiem (art. 24 ust. 3). Taki przepis poprawia przejrzystość stosunku wynikającego z obligacji przychodowych, wskazując, za co odpowiedzialny jest emitent. Możliwe jest zatem uprzywilejowanie obligatariuszy przychodowych do przychodów i majątku z przedsięwzięć przy jednoczesnym zapewnieniu odpowiedzialności emitenta całym jego majątkiem;

- zmniejszenie ryzyka wynikajacego z obligacji przychodowych przez wyłączenie wierzytelności wynikających z tych obligacji z postępowania układowego - z chwilą ogłoszenia upadłości lub otwarcia likwidacji stają się one wymagalne (art. 27).

Przepisem, który również może pozytywnie wpłynąć na rozwój rynku obligacji, jest umożliwienie emisji obligacji podmiotom nowo powstałym, które nie sporządzały dotąd sprawozdania finansowego. Przepis ten ma ogromne znaczenie również dla opisywanych obligacji przychodowych. Przedsięwzięcia finansowane za pomoca tego rodzaju obligacji dokonywane są najczęściej $\mathrm{w}$ formule project finance, w której podmiot emitujący przyjmuje postać spółki celowej, która jest spółką nowa, niemająca historii gospodarczej, czego skutkiem jest brak dotychczasowych sprawozdań finansowych. 
Wydaje się, że wprowadzone rozwiązania mogą przyspieszyć rozwój obligacji przychodowych. Problematyczne pozostaje jednak kilka kwestii, które moga nadal zniechęcać do emisji tych walorów.

Po pierwsze, jak pokazuje przykład Lublina, nie wszystkie samorządy chca korzystać z możliwości ograniczenia swojej odpowiedzialności, co może wynikać z obawy, że będzie to oznaczało konieczność zaproponowania inwestorom wyższego kuponu. Jednostki samorządu terytorialnego, decydując się na emisję obligacji przychodowych, stoją przed dylematem: korzyści z niezaliczania zobowiązań z tytułu tych obligacji do zadłużenia samorządu w kalkulacji IWZ (przez to możliwość zaciagania większego długu) a wysokość marży odsetkowej (wyższe koszty obsługi zadłużenia). Rozwiązaniem pośrednim jest emisja opisywanych obligacji bez ograniczania odpowiedzialności emitenta za dług. Pozostaje jednak pytanie, czy w takim przypadku można dług z takich obligacji wyłączyć z obliczania wartości IWZ.

Po drugie, ważnym problemem pozostaje kwestia funkcjonowania przedsięwzięć finansowanych obligacjami przychodowymi. Z jednej strony istnieje możliwość ograniczenia odpowiedzialności emitenta do przychodów generowanych przez przedsięwzięcia, a z drugiej - to emitent (lub jego organ założycielski) bezpośrednio kształtuje wielkość tych przychodów, nie kierując się wyłącznie dobrem przedsięwzięcia. Przykładowo, dotychczasowe emisje obligacji komunalnych dokonywane przez spółki komunalne ograniczały ich odpowiedzialność do przychodów, którymi były głównie opłaty płacone przez mieszkańców za świadczone przez nie usługi - wodno-kanalizacyjne i transportowe. Wysokość tych opłat jest z kolei zależna od decyzji rady (miejskiej) jednostki samorządu terytorialnego (organu założycielskiego spółki), który to organ nie kieruje się dobrem obligatariuszy, a dobrem mieszkańców (czyli wyborców). Tej kwestii jednak - jak się wydaje - nie można rozwiązá na poziomie ustawy o obligacjach. Jedynym sposobem jest całościowa zmiana systemu finansowania samorządów, a nawet szerzej: całego systemu finansowania zadań publicznych.

\section{PODSUMOWANIE}

Nowelizacja ustawy o obligacjach z 2015 r. wprowadziła szereg istotnych zmian, których celem było wsparcie rozwoju rynku obligacji nieskarbowych w Polsce. W niniejszym artykule skupiono się na zmianach dotyczących nowych rodzajów obligacji - podporządkowanych i wieczystych, a także istniejących już obligacji przychodowych.

Podsumowując podjęte rozważania, należy stwierdzić, że wprowadzenie $\mathrm{w}$ polskim prawie regulacji dotyczących funkcjonowania obligacji wieczystych i podporządkowanych było oczekiwane i konieczne. Doświadczenia światowe pokazuja, że istnienie takich rodzajów obligacji jest zasadne. Ich wykorzystanie wiąże się $\mathrm{z}$ wdrażaniem alternatywnych form finansowania. Zamiast stosowania instrumentów, które jednoznacznie można było określić mianem 
długu lub udziału, coraz częściej stosuje się finansowanie łączące cechy kapitału obcego i własnego, często określane mianem mezzanine. Nowa ustawa daje możliwości tworzenia przez spółki nowoczesnej struktury finansowania ich działalności. Inwestorzy z kolei otrzymują możliwość nabywania nowych form obligacji, które mogą oferować wyższą niż w przypadku obligacji zwykłych stopę zwrotu.

Ważnych zmian dokonano także w zakresie obligacji przychodowych. Instrument ten może być w Polsce emitowany od 15 lat, jednakże do tej pory wyemitowano zaledwie 8 serii tych walorów. Nowelizacja usuwa wiele przeszkód rozwoju tego rynku - przede wszystkim rozszerza grono potencjalnych emitentów. Jednakże z uwagi na to, że obligacje te mają służyć finansowaniu przedsięwzięć mających najczęściej charakter zadań publicznych, bariera pozostaje - zdaniem autora - kwestia zabezpieczania praw obligatariuszy na przychodach, których wielkość zależy nie od podmiotu zarządzającego przedsięwzięciem, a od decyzji organu samorządowego. Rozwiązanie tej kwestii wymaga jednak szerszych zmian niż tylko tych dokonanych w ustawie o obligacjach.

Wprowadzone zmiany mają szansę zwiększyć zainteresowanie potencjalnych emitentów i inwestorów obligacjami nieskarbowymi. Czas pokaże, czy zmiana otoczenia prawnego rynku będzie impulsem wystarczajacym do zwiększenia dynamiki jego rozwoju. Szczególnie interesujące wydaje się pytanie, czy nowe rodzaje obligacji staną się popularnymi instrumentami, czy jednak będą miały charakter niszowy i egzotyczny.

dr Marcin Wiśniewski

Uniwersytet Ekonomiczny w Poznaniu

marcin.wisniewski@ue.poznan.pl

\author{
SUBORDINATED, PERPETUAL AND REVENUE BONDS IN POLAND \\ - ATTEMPT TO ASSESS THE ECONOMIC IMPACT OF AMENDMENTS \\ TO THE ACT ON BONDS
}

\title{
Sum mary
}

In this article the author presents regulatory changes with respect to non-Treasury bonds in Poland, which have been introduced by the amendment to the Act on Bonds of 2015 and attempts to assess their economic effects. The aim of the new law was to support the development of the bond market. To this end new types of bond have been introduced: subordinated and perpetual bonds. Furthermore new regulations for revenue bonds have been adopted - bonds which had been defined in law but rarely used in practice. In this article the author discusses the potential economic impact of the changes to the law. 
